\title{
TYMPANIC AND TEMPORAL THERMOMETRY IN HYPOTHERMIA ASSESSMENT FOR ADULT IN INTRAOPERATIVE ABDOMINAL SURGERY ${ }^{1}$
}

\author{
Rutes de Fatima Terres Danczuk², Eliane Regina Pereira do Nascimento ${ }^{3}$, Patrícia Madalena Vieira Hermida \\ Luciana Bihain Hagemann ${ }^{5}$, Katia Cilene Godinho Bertoncello ${ }^{6}$, Walnice Jung ${ }^{7}$
}

${ }^{1}$ Text extracted from the thesis - Unplanned hypothermia evaluation during abdominal elective surgeries, presented to Programa de Pós-Graduação em Enfermagem (PEN), Universidade Federal de Santa Catarina (UFSC), 2014.

${ }^{2}$ M.Sc. in Nursing. University Hospital Polydoro Ernani de São Thiago (HU), PEN/UFSC. Florianópolis, Santa Catarina, Brazil. E-mail: rutes40@yahoo.com.br

${ }^{3}$ Ph.D. in Nursing. Professor, Nursing Department, PEN/UFSC. Florianópolis, Santa Catarina, Brazil. E-mail: eliane.nascimento@ ufsc.br

${ }^{4}$ Ph.D. student, PEN/UFSC. CAPES scholarship. Florianópolis, Santa Catarina, Brazil. E-mail: patymadale@yahoo.com.br

${ }^{5}$ M.S.c. in Health. Nurse at HU/UFSC. Florianópolis, Santa Catarina, Brazil. E-mail: lucianahagemann@gmail.com

${ }^{6}$ Ph.D. in Nursing Fundamentals. Professor of the Nursing Department, UFSC. Florianópolis, Santa Catarina, Brazil. E-mail: katia. bertoncello@ufsc.br

${ }^{7}$ Master's student, PEN/UFSC. Florianópolis, Santa Catarina, Brazil. E-mail: walnicejung@gmail.com

\begin{abstract}
Objective: to analyze the association between sociodemographic, clinical, operative and environmental characteristics with hypothermia events, measured intraoperatively by tympanic and temporal thermometers in adult patients undergoing elective abdominal surgery with visceral exposure.

Method: prospective quantitative, correlational, observational study. Data were collected by means of structured instrument containing the variables: age, Body Mass Index; American Society of Anesthesiologists class; type of anesthesia; time of surgery; tympanic and temporal temperature; temperature and relative humidity of the surgical room. Temperatures were assessed by methods of tympanic and temporal measurement in 63 patients. The data analysis sought an association between hypothermia and patient characteristics, type of anesthesia, surgical environment, according to the method of measurement and surgical time.

Results: Among the 63 patients, $15(23.8 \%)$ had hypothermia. Of the total ( $\mathrm{n}=15 ; 100 \%)$ number of hypothermic patients, $13(80 \%)$ had mild hypothermia. Moderate hypothermia was identified only by temporal thermometry in three (20\%) patients. Severe hypothermia was not identified, and in two $(13.3 \%)$ patients the hypothermia was identified only by temporal thermometry. Hypothermia had a statistically significant association only with age $(\mathrm{p}=0.0027)$ and $\operatorname{sex}(\mathrm{p}=0.015)$, when measuring tympanic temperature.

Conclusion: Only sex and age showed correlation with hypothermia during surgery measured by tympanic thermometry; no variable influenced hypothermia measured by temporal thermometry.

DESCRIPTORS: Hypothermia. Intraoperative period. Perioperative nursing. Elective surgical procedures. Body temperature. Thermometry. Anesthesia.

\section{TERMOMETRIA TIMPÂNICA ETEMPORAL NA AVALIAÇÃODA HIPOTERMIA NO INTRAOPERATÓRIO DE CIRURGIA ABDOMINAL EM ADULTOS}

\section{RESUMO}

Objetivo: analisar a associação entre características sociodemográficas, clínicas, operatórias e ambientais com a ocorrência de hipotermia medida por meio de termômetros timpânico e temporal, em pacientes adultos, no intraoperatório, submetidos à cirurgias abdominais eletivas com exposição visceral.

Método: estudo observacional prospectivo, quantitativo, correlacional. Os dados foram coletados mediante instrumento estruturado contendo as variáveis: idade; índice de massa corporal; classificação da American Society of Anesthesiologists; tipo de anestesia; tempo da cirurgia; temperatura timpânica e temporal; temperatura e umidade relativa da sala cirúrgica. Foram mensuradas as temperaturas pelos métodos de aferição timpânico e temporal em 63 pacientes. Na análise dos dados buscou-se associação da hipotermia com as características dos pacientes, do tipo de anestesia, do ambiente cirúrgico segundo o método de aferição e do tempo cirúrgico.

Resultados: dos 63 pacientes, $15(23,8 \%)$ apresentaram hipotermia. Do total ( $n=15 ; 100 \%)$ de pacientes hipotérmicos, 13 (80\%) tiveram hipotermia leve. A hipotermia moderada foi identificada apenas pela termometria temporal, em três (20\%) pacientes. Não houve hipotermia grave e em dois $(13,3 \%)$ pacientes a hipotermia ocorreu apenas na medida da termometria temporal. Na relação das variáveis, identificou-se que a hipotermia teve associação estatisticamente significante somente com a idade ( $p=0,0027)$ e o sexo ( $p=0,015)$, na aferição da temperatura timpânica.

Conclusão: apenas o sexo e a idade interferiram na hipotermia no intraoperatório pela termometria timpânica e nenhuma variável influenciou na hipotermia pela termometria temporal.

DESCRITORES: Hipotermia. Período intraoperatório. Enfermagem perioperatória. Procedimentos cirúrgicos eletivos. Temperatura corporal. Termometria. Anestesia. 


\title{
TERMOMETRÍA TIMPÁNICA Y TEMPORAL EN LA EVALUACIÓN DE HIPOTERMIA EN EL TRANS-OPERATORIO DE CIRUGÍA ABDOMINAL
}

\begin{abstract}
RESUMEN
Objetivo: analizar la asociación entre las características sociodemográficas, clínicas, operatorias y ambientales con la ocurrencia de hipotermia medida por medio de termómetros timpánicos y temporales, en pacientes adultos en el trans-operatorio sometidos a cirugías abdominales electivas con exposición visceral.
\end{abstract}

Métodos: estudio observacional, prospectivo, cuantitativo, correlacional. Los datos fueron recolectados mediante instrumento estructurado conteniendo las variables: edad; índice de massa corporal; classificación American Society of Anesthesiologists; tipo de anestesia; tiempo de la cirugía; temperatura timpánica y temporal; temperatura y humedad relativa a la sala quirúrgica. Fueron medidas las temperaturas por los métodos de afección timpánico y temporal en 63 pacientes. En el análisis de los datos se buscó la asociación de la hipotermia con las características de los pacientes, del tipo de anestesia, del ambiente quirúrgico segundo el método de afección y del tiempo quirúrgico.

Resultado: de los 63 pacientes, $15(23,8 \%)$ presentaron hipotermia. Del total (n=15; 100\%) de pacientes hipotérmicos, $13(80 \%)$ presentaron hipotermia leve. La hipotermia moderada fue identificada apenas por la termometría temporal, en tres (20\%) pacientes. No hubo hipotermia grave y en dos $(13,3 \%)$ pacientes a la hipotermia ocurrió apenas en la medida de la termometría temporal. En la relación de las variables, identificación que la hipotermia tuvo asociación estadísticamente significante solamente con la edad ( $p=0,0027)$ y el sexo ( $p=0,015)$, en la afección de la temperatura timpánica.

Conclusión: apenas el sexo y la edad interfirieron en la hipotermia en el trans-operatorio por la termometría timpánica y ninguna variable influenció por la termometría temporal.

DESCRIPTORES: Hiportemia. Periodo intraoperatorio. Enfermería perioperatoria. Procedimientos quirúrgicos electivos. Temperatura corporal. La Termometría. Anestesia.

\section{INTRODUCTION}

Hypothermia is defined as a body temperature below $36^{\circ} \mathrm{C}$, and when this occurs during surgery or in the immediate postoperative period, it is called perioperative hypothermia. This is a common problem and usually under diagnosed, as temperature monitoring remains an underused practice. ${ }^{1}$

The patient undergoing surgery is at risk of developing hypothermia in the intraoperative period, as the result of factors such as extremes of age, anesthetic agents, room temperature, time of exposure to the low temperature environment, cold venous infusions, metabolic diseases, among others. ${ }^{2}$

However, heat loss may occur in patients undergoing surgery with greater exposure of cavities and central organs, ${ }^{3}$ such as abdominal surgery with visceral exposure, which is studied in this research. In this type of surgery, which is usually extended, lasting more than 30 minutes, there is a greater possibility of decreasing temperature at the end of the procedure. ${ }^{4}$ The concern with the development of intraoperative hypothermia exists especially in patients undergoing major surgery, which require long periods of anesthesia. ${ }^{5}$

Complications of hypothermia in the intraoperative period that are highlighted by the literature include: coagulopathy and increased need for blood transfusion, morbid coronary events such as heart attack, tachycardia and hypertension, surgical site infection, thermal discomfort, tremors, decreased drug metabolism, and prolonged recovery. Due to the serious consequences associated with hypothermia, the standard of care is to monitor the body temperature during the anesthesia, and maintain a stable temperature. ${ }^{6}$

Although central thermometry via pulmonary artery is the best indicator, and the gold standard for evaluating the patient's thermal state, the invasive measurement is inconvenient. ${ }^{4}$ When invasive thermometry methods are not available, non-invasive techniques are used (oral, axillary, tympanic or temporal artery). ${ }^{7}$

In this study, tympanic (TT) and temporal (TTE) thermometry were used because TT is considered the most trustworthy in terms of the thermoregulatory center temperature in the hypothalamus; 8 TTE was introduced in the 1990s as a measure that records temperatures comparable with the core temperature, and since then, studies have been conducted to test its accuracy and reliability. ${ }^{9}$

One study on the accuracy of TT found that it is a method that can be used in clinical practice due to its safety, ease of use and the rapid speed of temperature reading. However, the research did not include patients with hypothermia, and recommended further studies with this group to support the wider use of tympanic thermometers. ${ }^{10}$

Research that analyzed the relationship between the measurement of temporal, oral and axillary temperatures supports the use of TTE in surgical normothermic adult patients, who do not require invasive monitoring. However, the authors indicate that the performance of TTE under hypothermic conditions remains a research question. ${ }^{9}$

As the institution where the study was conducted does not use any intraoperative temperature 
measurement method, the use of TT and TTE were options to be analyzed to due to their accuracy. It is believed that the comparison of these two methods during intraoperative surgery with visceral exposure can support the choice of one of them by the institution.

Given the above, and considering the relevance of the theme for intraoperative patient care, the question is: what is the association between sociodemographic, clinical, operative and environmental characteristics with hypothermia events measured by tympanic and temporal thermometers in intraoperative adult patients undergoing elective abdominal surgery with visceral exposure?

In order to answer to this question this study aimed to analyze the association between sociodemographic, clinical, operative and environmental characteristics with hypothermia measured by tympanic and temporal thermometers, in adult intraoperative patients undergoing elective abdominal surgery with visceral exposure.

It is believed that the contribution of this research for nursing is that the evidence found could aid in choosing the most suitable non-invasive method for assessing the temperature of patients in similar conditions as those in this research.

\section{METHOD}

Quantitative, prospective, correlational, observational study, conducted in the operating room of a public hospital, a reference site for medium and extensive surgeries, in the state of Santa Catarina, Brazil.

The hospital has 270 beds, including clinical, surgical, pediatric, gynecological, emergency, and maternity (neonatology and rooming-in), intensive care unit services, dialysis, general and specialized outpatient, radiology, hemodynamic, and a surgical center. The surgical center has five operating rooms, one room for procedures with local anesthesia, four for small, medium and extensive surgery procedures that require general anesthesia and a post-anesthesia care unit (PACU). All operating rooms have similar characteristics regarding size, air conditioner, as well as the provision of surgical equipment.

Among the types of surgeries performed at the hospital are: digestive tract, reproductive, urinary, musculoskeletal, circulatory, corrective and transplant surgeries. We chose to study the patients having abdominal surgery with visceral exposure, as these are more likely to result in hypothermia due to the time of organ exposure.
Data collection occurred between August and November of 2013. The study population was 263 patients who underwent elective surgery of the abdominal cavity with visceral exposure, which was the amount of surgeries performed in the data collection period. Non probabilistic, sequential sampling was used, and the sample consisted of 63 patients who met the inclusion criteria, namely: age between 18-59 years; both sexes; minimum operating time of 120 minutes; body mass index (BMI) equal to or less than $35 \mathrm{~kg} / \mathrm{m}^{2}$; and American Society of Anesthesiologists (ASA) class I, II, and III.

Recruitment of subjects was performed by one of the researchers, and occurred in two stages: one before surgery and another intraoperatively. In the first stage, after consulting the surgical map of surgeries to be performed on the following day, the potential patients for inclusion were identified, by the type of surgery. A visit was conducted prior to the surgery with the patient, to present the objectives of the study, and to collect information on comorbidities. Then, the Free and Informed Consent Term was signed, and some procedures such as anthropometric measures, and excessive earwax assessment were recorded on the instrument itself. In the second stage of recruitment, data regarding age, BMI and ASA were extracted from the patient record and recorded, as well as, the observation of the time of surgery, as only those with a minimum of 120 minutes were included.

For calculation of BMI, the World Health Organization (WHO) classification was used, ${ }^{11}$ i.e.: normal (18.50 to $\left.24.99 \mathrm{~kg} / \mathrm{m}^{2}\right)$; overweight (25 to $29.99 \mathrm{~kg} / \mathrm{m}^{2}$ ); obesity I ( 30 to $34.99 \mathrm{~kg} / \mathrm{m}^{2}$ ); and for hypothermia, the classification adopted was: mild (temperature 35.1 to $35.9^{\circ} \mathrm{C}$ ); moderate (below $35^{\circ} \mathrm{C}$ ); and severe $\left(\leq 33.9^{\circ} \mathrm{C}\right) .^{2}$

The same researcher performed data collection during surgery by means of observation and recording on a structured instrument, which included information regarding age, BMI, ASA, type of anesthesia, surgery time, tympanic and temporal temperature, as well as temperature and relative humidity of the surgical room. Three experts (one nurse, one anesthesiologist, and one surgeon) validated this instrument for face (clarity/comprehension) and content (relevance) validity. A pre-test with five patients was performed, and adjustments to the instrument were not necessary.

The TTs and TTEs were performed on arrival of the patient to the operating room (before anesthesia), and immediately after anesthetic induction, at an interval of 15 and 30 minutes in the first and 
second hour, respectively. With the same frequency, the temperature and humidity of the operating room were checked. The surgeries were performed in four operating rooms for small, medium and extensive procedures, all of them with similar characteristics. The thermometry was performed with the tympanic thermometer Adtemp®TM421, and the temporal with the Beurer Stirnthermoeter ${ }^{\circledR}$ FT60, measured simultaneously. All patients were evaluated with the same tympanic and temporal apparatus. The thermohygrometer, More Fitness $₫$, was used to verify the temperature and humidity of the operating room, which was positioned against the wall, with an approximate distance of $130 \mathrm{~cm}$ from the patient.

The data collected were organized in spreadsheets in Microsoft Office Excel, version 15.0.44 (2013). For data analysis, descriptive statistics were used, and the Kolmogorov-Smirnov, Kruskal-Wallis and Mann Whitney tests, with a significance level of $\alpha=0.05$, using the SestatNet software. ${ }^{12}$ The calculation of mean temperatures was performed in accordance with the measurement method (TT or $\mathrm{TE}$ ), and thereafter, the statistical tests were performed. In all calculations, all the 63 patients who constituted the sample were included.

The TTs and the TTE had values ranging from zero to seven, which quantified the prevalence of hypothermia. The value of zero indicates that no intraoperative hypothermia occurred; seven indicates that the patient was in a hypothermic state for all measurements.

The research project was approved by the Research Ethics Committee of the Universidade Federal de Santa Catarina, N. 374659/2013, CAAE 14708013.9.0000.0121, and according to Resolution N. 466/12 of the National Health Council.

\section{RESULTS}

From the sample of 63 patients, the female gender predominated $(n=44 ; 69.8 \%)$ and the mean age was 45.4 years (21-59). With regard to categorization of BMI, $44(69.8 \%)$ patients were classified in a range lower than $30 \mathrm{~kg} / \mathrm{m}^{2}$, and $19(30.2 \%)$ had a degree of obesity I ( 30 to $\left.34.9 \mathrm{~kg} / \mathrm{m}^{2}\right)$. Six $(9.5 \%)$ patients had ASA I, 45 (71.4\%) ASA II, and 12 (19.1\%) ASA III. General anesthesia associated with epidural was the prevalent type of anesthesia in $38(60.3 \%)$ patients, followed by general anesthesia in $16(25.4 \%)$ and spinal anesthesia in nine (14.3\%) interventions.

The temperature of the operating room during the study ranged from $22.2^{\circ} \mathrm{C}$ to $23.1^{\circ} \mathrm{C}$ (mean of $22.6^{\circ} \mathrm{C}$ ). The humidity of the operating room ranged from $42 \%$ to $76 \%$, with a mean of $59 \%$.

The patient temperature during the surgical procedure varied according to the two methods of measurement used, with different means and standard deviations (SD). The larger SD (0.7) was found at two surgical times, at 60 and 90 minutes, when measuring the TTE; while in the TT measurement, the larger SD (0.6) was identified after 15 minutes. In the $\mathrm{TT}$, the mean temperature was $36.05^{\circ} \mathrm{C}$ (SD 0.50 ), while in the TTE the mean was $36.1^{\circ} \mathrm{C}$ (SD 0.63). Measurement with TT demonstrated more accurate results, i.e., less variation around the mean temperature (Table 1).

However, data analysis did not demonstrate statistically significant differences between the TTE and TT at 15, 30, 45, 60, 90 and 120 minutes. The TTE was not significantly higher than the TT, and both were able to detect the occurrence of hypothermia at different intraoperative times, which means that the two techniques of body temperature verification had similar results.

Table 1 - Temperature measured by tympanic and temporal thermometry of intraoperative patients during elective abdominal surgery with visceral exposure. Florianópolis, SC, Brazil, 2013. (n=63)

\begin{tabular}{|c|c|c|c|c|c|c|}
\hline \multirow{2}{*}{$\begin{array}{c}\text { Time of } \\
\text { measurement }\end{array}$} & \multicolumn{3}{|c|}{ Temperature by tympanic thermometry } & \multicolumn{3}{|c|}{ Temperature by temporal thermometry } \\
\hline & Mean & $\mathrm{SD}^{*}$ & Interval† & Mean & $\mathrm{SD}^{*}$ & Interval† \\
\hline After induction & 36.35 & 0.48 & $35.1-37.8$ & 36.37 & 0.57 & $35.5-37.7$ \\
\hline $15 \mathrm{~min}$ & 36.09 & 0.60 & $34.9-37.7$ & 36.23 & 0.49 & $35.1-37.2$ \\
\hline $30 \mathrm{~min}$ & 36.03 & 0.51 & $34.7-36.8$ & 36.00 & 0.67 & $34.8-37.0$ \\
\hline $45 \mathrm{~min}$ & 35.99 & 0.48 & $34.9-36.9$ & 35.07 & 0.56 & $35.1-37.2$ \\
\hline $60 \mathrm{~min}$ & 35.98 & 0.42 & $35.1-36.9$ & 35.90 & 0.70 & $34.3-37.5$ \\
\hline $90 \min$ & 35.98 & 0.44 & $35.3-37.2$ & 36.03 & 0.70 & $34.9-37.8$ \\
\hline $120 \mathrm{~min}$ & 35.93 & 0.45 & $35.3-37.5$ & 36.12 & 0.61 & $35.0-37.7$ \\
\hline Total & 36.05 & 0.50 & $34.7-37.8$ & 36.10 & 0.63 & $34.3-37.8$ \\
\hline
\end{tabular}

*SD: Standard deviation; †Interval: minimum -maximum temperatures. 
Among the $63(100 \%)$ patients studied, 15 $(23.8 \%)$ presented hypothermia; from this total $(\mathrm{n}=$ $15,100 \%), 13(80 \%)$ had mild hypothermia, and only three $(20 \%)$ experienced moderate hypothermia, which was identified by the TTE. Severe hypothermia did not occur, and in two $(13.3 \%)$ patients, the hypothermia was observed only in the TTE measurement (Table 2).

Although hypothermic patients are identified in all age groups, the age ratio analysis with hypothermia, verified by TT and TTE, a statistically significant association was obtained between these variables only using the tympanic thermometry $(\mathrm{p}=0.0027)$.

Hypothermia predominated in female patients $(n=9 ; 60 \%)$, which also showed the lowest temperature $\left(34.5^{\circ} \mathrm{C}\right)$ in two patients $(13.3 \%)$ by means of TTE, after 60 minutes of surgery. According to the TT, the frequency of hypothermia $(n=6 ; 40 \%)$ was similar in both sexes, registered post-induction, at 60 and 120 minutes (Table 2). The ratio of the variable, sex, with hypothermia identified by TT showed a statistically significant association between these variables $(\mathrm{p}=0.015)$, as with this method of measurement, hypothermia was not expressed similarly in female and male patients; this was unlike what happened using the TTE method $(\mathrm{p}=0.0873)$.

Regarding the BMI, the findings cannot confirm that the patient with obesity I will present with hypothermia, because among the hypothermic patients, eight $(53.3 \%)$ presented with this index (30 to $34.99 \mathrm{~kg} / \mathrm{m}^{2}$ ), four $(26.7 \%$ ) with normal BMI, and three (20\%) were overweight. The BMI relationship with hypothermia measured by tympanic and temporal methods obtained, respectively, $\mathrm{p}=0.4176$ and $p=0.4785$, and did not show association between these variables. Hypothermia identified by these two methods was expressed similarly in normal, overweight and obesity I patients.

All hypothermic patients exhibited ASA II or III. Although the frequency of hypothermia was higher $(n=12 ; 80 \%)$ in patients classified as ASA II, those with ASA III $(n=2 ; 13.3 \%)$ presented hypothermia with greater intensity $\left(34.5^{\circ} \mathrm{C}\right)$, when assessed by TTE (Table 2). However, there was no association between ASA with hypothermia verified by tympanic $(p=0.4322)$ and temporal $(p=0.4245)$ thermometry.

All hypothermic patients $(\mathrm{n}=15,100 \%)$ received general anesthesia $(n=4,26.7 \%)$ or combined, i.e. general anesthesia associated with peridural $(n=11$; $73.3 \%)$. The type of anesthesia also did not show association with hypothermia by TT $(p=0.8187)$ or TTE $(p=0.6035)$.

The longer the operating time, the higher the frequency of hypothermia by TT, which is inversely proportional to the TTE, whose frequency of hypothermia was higher after anesthesia induction, showing it to be more sensitive to these medications. According to the data, TT is more accurate in assessing the patient in the intraoperative abdominal surgery throughout the surgical procedure, maintaining a more stable temperature measurement when compared to TTE.

Table 2 - Hypothermia by tympanic and temporal thermometry according to age, body mass index, American Society of Anesthesiologists and anesthesia. Florianópolis, SC, Brazil, 2013. (n=15)

\begin{tabular}{|c|c|c|c|c|c|c|c|c|c|c|}
\hline \multirow[t]{2}{*}{$\begin{array}{c}\text { Age } \\
\text { (years) }\end{array}$} & \multirow[t]{2}{*}{ Sex* } & \multirow[t]{2}{*}{$\begin{array}{c}\mathrm{BMI} \dagger \\
\mathrm{Kg} / \mathrm{m}^{2}\end{array}$} & \multirow[t]{2}{*}{ ASA $\ddagger$} & \multirow[t]{2}{*}{$\begin{array}{l}\text { Anes- } \\
\text { thesia§ }\end{array}$} & \multicolumn{3}{|c|}{$\begin{array}{l}\text { Hypothermia by temporal ther- } \\
\text { mometry }\left({ }^{\circ} \mathrm{C}\right)\end{array}$} & \multicolumn{3}{|c|}{$\begin{array}{c}\text { Hypothermia by tympanic } \\
\text { thermometry }\left({ }^{\circ} \mathrm{C}\right)\end{array}$} \\
\hline & & & & & $\begin{array}{l}\text { Post-in- } \\
\text { duction }\end{array}$ & $60^{\prime \prime}$ & $120^{\prime \prime}$ & $\begin{array}{l}\text { Post- in- } \\
\text { duction }\end{array}$ & $60^{\prime \prime}$ & $120^{\prime \prime}$ \\
\hline 59 & $\mathrm{M}$ & 23.7 & 2 & $G \& P$ & 35.5 & 35.7 & 35.4 & 35.8 & 35.8 & 35.9 \\
\hline 58 & M & 28.3 & 2 & $G \& P$ & 35.8 & 35.3 & 36.5 & 36.0 & 35.1 & 35.7 \\
\hline 55 & $\mathrm{~F}$ & 31.4 & 3 & $G \& P$ & 35.5 & 36.0 & 36.5 & 36.6 & 35.8 & 35.5 \\
\hline 53 & F & 25.0 & 2 & $G \& P$ & 35.7 & 35.8 & 36.0 & 36.0 & 35.1 & 35.5 \\
\hline 53 & F & 32.4 & 3 & $G \& P$ & 35.6 & 34.5 & 35.5 & 35.1 & 36.0 & 35.4 \\
\hline 53 & F & 32.4 & 3 & $G \& P$ & 35.6 & 34.5 & 35.5 & 35.1 & 36.0 & 35.6 \\
\hline 52 & M & 21.6 & 2 & $G \& P$ & 35.6 & 34.7 & 36.4 & 36.6 & 35.4 & 35.5 \\
\hline 49 & M & 25.8 & 2 & $G \& P$ & 35.8 & 35.5 & 35.7 & 35.4 & 35.5 & 35.5 \\
\hline 48 & $\mathrm{~F}$ & 30.4 & 2 & G & 35.7 & 35.1 & 36.0 & 36.5 & 36.1 & 35.9 \\
\hline 48 & F & 30.4 & 2 & G & 35.7 & 35.1 & 35.5 & 36.5 & 36.1 & 36.0 \\
\hline 46 & F & 30.0 & 2 & $G \& P$ & 35.6 & 35.2 & 36.0 & 36.0 & 36.5 & 35.8 \\
\hline 46 & $\mathrm{~F}$ & 30.0 & 2 & $G \& P$ & 35.6 & 35.2 & 36.0 & 36.0 & 36.5 & 35.8 \\
\hline
\end{tabular}




\begin{tabular}{|c|c|c|c|c|c|c|c|c|c|c|}
\hline \multirow[t]{2}{*}{$\begin{array}{c}\text { Age } \\
\text { (years) }\end{array}$} & \multirow[t]{2}{*}{ Sex* } & \multirow[t]{2}{*}{$\begin{array}{c}\mathrm{BMI \dagger} \\
\mathrm{Kg} / \mathrm{m}^{2}\end{array}$} & \multirow[t]{2}{*}{ ASA } & \multirow[t]{2}{*}{$\begin{array}{l}\text { Anes- } \\
\text { thesia§ }\end{array}$} & \multicolumn{3}{|c|}{$\begin{array}{l}\text { Hypothermia by temporal ther- } \\
\text { mometry }\left({ }^{\circ} \mathrm{C}\right)\end{array}$} & \multicolumn{3}{|c|}{$\begin{array}{l}\text { Hypothermia by tympanic } \\
\text { thermometry }\left({ }^{\circ} \mathrm{C}\right)\end{array}$} \\
\hline & & & & & $\begin{array}{l}\text { Post-in- } \\
\text { duction }\end{array}$ & $60^{\prime \prime}$ & $120^{\prime \prime}$ & $\begin{array}{l}\text { Post- in- } \\
\text { duction }\end{array}$ & $60^{\prime \prime}$ & $120 "$ \\
\hline 44 & M & 23.6 & 2 & G & 35.9 & 36.9 & 36.8 & 36.0 & 35.9 & 35.4 \\
\hline 36 & F & 34.5 & 2 & G \& P & 35.8 & 36.8 & 37.2 & 36.7 & 36.4 & 36.6 \\
\hline 26 & M & 19.6 & 2 & G & 35.8 & 35.5 & 35.8 & 36.5 & 35.3 & 35.3 \\
\hline
\end{tabular}

*M: male, F: female; † body mass index; A American Society of Anesthesiologists; §G: general; G \& P: general and peridural.

The mean temperature of the operating room, from patient arrival up to 45 minutes into surgery, was $21.7^{\circ} \mathrm{C}$ (SD 1.9) to $22.3^{\circ} \mathrm{C}$ (SD 1.3), and thereafter, it decreased at a slow pace until 90 minutes into surgery, when it then remained stable (Table 3). The observed temperature difference was statistically significant. As all measurement conditions were similar, the temperature of the operating room was not a factor that interfered with hypothermia of the patient.

The humidity of the operating room air was analyzed to identify whether it was a causal factor for hypothermia. This moisture had its highest level in the post-anesthetic induction time, with a mean value of $58.3 \%$ (SD 6.0) of moisture and, thereafter, decreased to $54.7 \%$ (SD 4.5) after 90 minutes of surgery. The variance of air humidity was also slightly higher at the beginning of surgery.

Therefore, not all of the air humidity measurements were equal $(p=0.000004)$, since there was at least one condition that differed from the others. Statistically significant differences was obtained between the condition of arrival, 90 and 120 minutes, and the post-induction condition at 45, 60, 90 and 120 minutes.

Table 3 - Temperature and air humidity in the operating room from patient arrival until 120 minutes intraoperatively. Florianópolis, SC, Brazil, 2013. (n=15)

\begin{tabular}{lcccccc}
\hline \multirow{2}{*}{ Measurement time } & \multicolumn{3}{c}{ Room temperature $\left({ }^{\circ} \mathbf{C}\right)$} & \multicolumn{3}{c}{ Air humidity (\%) } \\
& Mean & SD* & Interval $\dagger$ & Mean & SD & Interval \\
\hline Arrival & 21.7 & 1.9 & $17.5-24.5$ & 57.7 & 6.0 & $48-68$ \\
Post-induction & 21.9 & 1.8 & $18.2-24.5$ & 58.3 & 6.0 & $44-68$ \\
15 min & 22.0 & 1.6 & $18.2-24.3$ & 57.8 & 6.7 & $48-68$ \\
$30 \mathrm{~min}$ & 21.7 & 1.3 & $18.6-23.6$ & 56.6 & 6.4 & $49-68$ \\
$45 \mathrm{~min}$ & 22.3 & 1.3 & $18.6-23.6$ & 55.5 & 6.4 & $45-68$ \\
$60 \mathrm{~min}$ & 20.9 & 1.1 & $18.7-22.9$ & 55.5 & 5.7 & $49-68$ \\
$90 \mathrm{~min}$ & 20.8 & 1.1 & $18.9-23.4$ & 54.7 & 4.5 & $48-61$ \\
$120 \mathrm{~min}$ & 20.8 & 1.0 & $18.9-22.7$ & 55.5 & 4.2 & $48-61$ \\
Total & $\mathbf{2 1 . 4}$ & $\mathbf{0 . 5}$ & $\mathbf{1 7 . 5 - 2 4 . 5}$ & $\mathbf{5 6 . 5}$ & $\mathbf{1 . 4}$ & $\mathbf{4 4 - 6 8}$ \\
\hline
\end{tabular}

*SD: Standard deviation; †Interval: minimum-maximum temperatures

\section{DISCUSSION}

The results of body temperature identified by the TT and the TTE were similar with the two assessment methods; the limitations of each site should be considered when the professional is performing thermometry. These limitations are presented in studies ${ }^{7,13}$ involving this subject.

Patient age did not influence the occurrence of hypothermia in this study, but it was manifested differently according to age when measured by TT, while this was not the case with TTE. Other research performed intraoperatively in another large hospital identified similar results. ${ }^{14}$ Although the evidence is weak, extremes of age are considered risk factors for perioperative hypothermia, as shown by some studies; ${ }^{13,15-16}$ this population was not included in this survey, as only patients from 18 to 59 years was involved.

The relationship between sex and hypothermia evidenced in this research is supported by other studies, ${ }^{3,14,16}$ but the larger number of women in the sample may have influenced the higher frequency of hypothermia in this group. In addition, hypothermia measured by TTE was expressed similarly in 
male and female patients, different from that identified by TT, which proved to be different.

Although women experience lower heat loss than men during surgery, due to their higher percentage of adipose tissue that acts as a protective layer, their smaller amount of muscle and increased body surface ratio mass can make them more susceptible to heat loss to the environment. ${ }^{3}$ However, the American Society of PeriAnesthesia Nurses (ASPAN) classifies the evidence on the female sex factor as weak for the onset of perioperative hypothermia. ${ }^{15}$

This study demonstrated that BMI did not interfere with hypothermia. The statistical analysis to suggest that hypothermia verified by tympanic and temporal thermometry are similar between normal, overweight and obesity I patients. According to the ASPAN, normal and below normal BMI are risk factors with insufficient evidence for perioperative hypothermia. ${ }^{15}$

However, the relationship of BMI with perioperative hypothermia was reported in a national survey with obese and non-obese women undergoing elective open abdominal surgery. By using measures of oral and esophageal temperatures, different thermometry than that used in this study, obese women were shown to have a higher perioperative temperature and a lower incidence of hypothermia when compared to non-obese women. ${ }^{17}$ In the USA, one study comparing oral, temporal and bladder thermometry supported a BMI below $30 \mathrm{~kg} / \mathrm{m}^{2}$ as a risk factor for hypothermia. ${ }^{13}$

In the present study, hypothermia was identified in patients with ASA II and III, that is, those with comorbidities. However, statistically, no association was identified between ASA classification and hypothermia, with either the tympanic or the temporal thermometry. National studies ${ }^{2,18-19}$ on hypothermia include ASA in the profile description of surgical patients, but not as a factor that interferes with the occurrence of hypothermia. In one of those studies, most patients were classified as ASA I, followed by ASA II, and no patients with ASA III, ${ }^{2}$ distinct from the results of this research. In other investigations, the highest incidence was ASA II. ${ }^{18-19}$ Research that specifically analyzed the factors related to the loss of body heat in the intraoperative period did not include the ASA as a variable in the study. ${ }^{8}$

In a study in Spain with adults undergoing some kind of elective surgery, the association between ASA classification and hypothermia was also rejected. ${ }^{16}$ However, the National Institute for Health and Care Evidence (NICE) considers patients to be at high risk of perioperative hypothermia when they have two or more of the following risk factors: ASA greater than I, preoperative temperature below $36^{\circ} \mathrm{C}$, combined and regional anesthesia, medium and extensive surgery, and patients with cardiovascular history. ${ }^{20}$

Regarding the type of anesthesia, a study that used axillary thermometry in the perioperative period showed a higher frequency of mild and moderate hypothermia in patients undergoing general anesthesia, followed by combined, ${ }^{21}$ which differs from the findings of the present research, which had the largest amount of hypothermic patients among those undergoing combined anesthesia.

In the list of variables, the results of this research confirm that anesthesia did not influence the loss of body heat of patients in the intraoperative period, ${ }^{8}$ however, the literature indicates that combined anesthesia presents a situation of increased risk of intraoperative hypothermia. ${ }^{22}$ Research with patients in the intraoperative period of abdominal surgery, which used TT, found that combined anesthesia was a statistically significant variable to predict hypotermia. ${ }^{14}$ A study conducted in China suggested that this type of anesthesia increased the risk of hypothermia, although the results did not reach statistical significance. ${ }^{5}$

The possibility of the patient developing hypothermia who received combined anesthesia increases mainly due to inhibition of the thermoregulatory center, combined with the impaired ability to maintain compensatory mechanisms, such as: tremors, piloerection, peripheral vasoconstriction induced by cold, thus contributing to lower temperatures. ${ }^{6,23}$

Exposure to the cold environment of the operating room, usually combined with the inhibition of thermoregulation induced by anesthetics, produces hypothermia. ${ }^{6}$ Heat loss occurs through four mechanisms: radiation, conduction, evaporation, and convection. ${ }^{3}$

Regarding the temperature of the operating rooms, the parameters remained close to the limits recommended by the Association of Perioperative Registered Nurses (AORN), which recommends between 20 and $23^{\circ} \mathrm{C} .{ }^{24}$

Research corroborates the findings of this study in which the temperature of the operating room did not influence the loss of body heat of patients in the intraoperative period, although this result was evident in elderly patients. ${ }^{8}$

The recommended parameters for the tem- 
perature of the operating room were not followed in other studies. ${ }^{2-3,13}$ A study conducted in Fortaleza-CE (Brazil), showed that in 120 surgical procedures, the room temperatures were not in accordance with the recommendations, achieving a minimum of $18.1^{\circ} \mathrm{C} . .^{3}$

In another study in the municipality of SantosSP (Brazil), the room temperature the was even lower $\left(15\right.$ and $\left.16.9^{\circ} \mathrm{C}\right)$ than the recommendation in $43.3 \%$ of the cases, an aspect that may have contributed to the development of hypothermia. ${ }^{2}$

In a study in Belo Horizonte-MG (Brazil), the temperature of the operating room was was controlled within the recommended range. Room temperature significantly influences the occurrence of hypothermia and should be controlled, because every $1^{\circ} \mathrm{C}$ increase in room temperature lowers the chance of hypotermia. ${ }^{18}$ In the international scenario, a mean temperature of $20^{\circ} \mathrm{C}$ in the operating room was identified, with a minimum of $18.3^{\circ} \mathrm{C}$ and a maximum of $23.3^{\circ} \mathrm{C}$. Based on the findings, it is stated that the ambient temperature below $20^{\circ} \mathrm{C}$ constitutes a risk factor for hypothermia. ${ }^{13}$

The air humidity did not always follow the reference of values between 30 and $60 \% .{ }^{24}$ Nevertheless it was found that this variable was not statistically associated with hypothermia. Further investigations corroborated that room humidity did not interfere with hypothermia. ${ }^{8,18}$

A study evaluating the variations of temperature and humidity of the operating room showed a statistically significant association between both. Thus, the lower the temperature of the room, the lower the humidity. ${ }^{25}$

This highlights the importance of constant evaluation of temperature and humidity of the operating room environment, in order to promote safe patient care. ${ }^{25}$ Patient safety is the focus of the Brazilian Network of Nursing and Patient Safety (Rede Brasileira de Enfermageme Segurança do PacienteREBRAENSP ) which has as one of its strategies to promote discussion and dissemination of protocols released by the Ministry of Health, among which is "safe surgery". ${ }^{26}$

\section{CONCLUSION}

Among the variables (sex, age, BMI, ASA, type of anesthesia, temperature and humidity of the operating room environment) only sex and patient age demonstrated influence on hypothermia, measured by tympanic thermometry, in the intraoperative period. No variable showed an influence on hypothermia when temporal thermometry was used.
This research did not show that the occurrence that hypothermia in the intraoperative period is more related to the extremes of age, due to age group of patients included in this study, but demonstrated the importance of thermometry, especially in patients at high surgical risk, as hypothermia was present in those patients with ASA II and III.

The study revealed that the two temperature assessment methods used were effective in detecting hypothermia at different times in the intraoperative period, however, the tympanic thermometry showed greater stability with less variation around the mean temperature, which indicates its application. However, as the values for the temperature verified by the temporal method were also within the acceptable range as defined by experts, the results suggest that both methods of thermometry used have potential for use in the context of elective abdominal surgery with visceral exposure, as noninvasive devices for measurements of body temperature. It is expected that these results will make the surgical team, especially the nursing team, more aware of the need to use one of these temperature verification methods.

With regard to study limitations, the sample size requires caution with generalizing the results. On the other hand, given the lack of studies on the subject, especially on the national scene, the results may support the development of research with more representative samples and of an experimental type, using tympanic and temporal thermometry as well as other non-invasive methods of temperature measurement. It should be noted that the patients in this study were not undergoing therapeutic hypothermia, thus the results cannot be extrapolated to this condition.

\section{REFERENCES}

1. Reales-Osorio RJ, Palomino-Romero R, Ramos-Clason EC, Pulgarín-Díaz JI, Guette-Viana A. Prevención de hipotermia perioperatoria utilizando bolsas plásticas de polietileno, em pacientes sometidos a cirugía bajo anestesia general. Rev Ciênc Bioméd [Internet]. 2014 Jan-Jun [cited 2015 Nov 30]; 5(1):23-8. Available from: http:/ / revistas.unicartagena.edu.co/index.php/ cienciasbiomedicas/article/view/1197/1107

2. Mattia AL, Barbosa MH, Rocha AM, Farias HL, Santos CA, Santos DM. Hypothermia in patients during the perioperative period. Rev Esc Enferm USP [Internet]. 2012 Feb [cited 2015 Nov 28]; 46(1):60-6. Available from: http://www.scielo.br/scielo.php?pid=S008062342012000100008\&script=sci_arttext\&tlng=en

3. Muniz GS, Teles NSB, Leitão IMTA, Almeida PC, Leitão MC. Hipotermia acidental: implicações para 
os cuidados de enfermagem no transoperatório. Rev SOBECC [Internet]. 2014 Jan-Mar [cited 2015 Nov 30]; 19(1):79-86. Available from: http://itarget.com.br/ newclients/sobecc.org.br/2015/pdfs/site_sobecc_ v19n2/04_sobecc_v19n2.pdf

4. Kasai T, Hirose M, Yaegashi K, Matsukawa T, Takamata A, Tanala Y. Preoperative risk factors of intraoperative hypothermia in major surgery under general anesthesia. Anesth Analg [Internet]. 2002 Nov [cited 2016 Jul 28]; 95 (5):1381-3. Available from: http:/ /journals.lww.com/anesthesia-analgesia/ Fulltext/2002/11000/Preoperative_Risk_Factors_of_ Intraoperative.51.aspx

5. Yi J, Xiang Z, Deng X, Fan T, Fu R, Geng W, et al. Incidence of inadvertent intraoperative hypothermia and its risk factors in patients undergoing general anesthesia in Beijing: a prospective regional survey. PLoS ONE [Internet]. 2015 Sep [cited 2016 Jul 29]; 10(9):e0136136. Available from: http://www.ncbi. nlm.nih.gov/pmc/articles/PMC4567074/pdf/ pone.0136136.pdf

6. Sessler DI. Temperature monitoring: the consequences and prevention of mild perioperative hypothermia. South Afr J Anaesth Analg [Internet]. 2014 May [cited 2015 Nov 30]; 20(1):25-31. Available from: http:/ / www.tandfonline.com/doi/pdf/10.1080/22201173. 2014.10844560

7. Counts D, Acosta M, Holbrook H, Foos E, HaysPonder K, Macairan O. Evaluation of temporal artery and disposable digital oral thermometers in acutely ill patients. Medsurg Nurs [Internet]. 2014 Jul-Aug [cited 2015 Nov 30]; 23(4):239-44. Available from: http:/ / web.a.ebscohost.com/ehost/pdfviewer/ pdfviewer?sid=324c0450-ba19-45b0-99bf-d9c1a7393 3 e4\%40sessionmgr4007\&vid $=5 \&$ hid $=4209$

8. Tramontini CC, Graziano KU. Fatores relacionados à perda de calor corporal no intra-operatório: análise de duas intervenções de enfermagem. Ciênc Cuid Saúde [Internet]. 2012 [cited 2015 Nov 15]; 11(supl.):220-5. Available from: http://www.periodicos.uem.br/ojs/ index.php/CiencCuidSaude/article/view/17079/pdf

9. Barringer LB, Evans CW, Ingram LL, Tisdale PP, Watson SP, Janken JK. Agreement between temporal artery, oral, and axillary temperature measurements in the perioperative period. J Perianesth Nurs [Internet]. 2011 Jun [cited 2015 Nov 15]; 26(3):14350. Available from: http://www.jopan.org/article/ S1089-9472(11)00158-4/pdf

10. Gasim GI, Musa IR, Abdien MT, Adam I. Accuracy of tympanic temperature measurement using an infrared tympanic membrane thermometer. BMC Res Notes [Internet]. 2013 May [cited 2015 Nov 15]; 6:194. Available from: http:/ / www.ncbi.nlm.nih.gov/pmc/ articles/PMC3658932/pdf/1756-0500-6-194.pdf

11. World Health Organization. The problem of overweight and obesity. In: Obesity: preventing and managing the global epidemic. Report of a World Health Organization consultation [Internet]. Geneva:
World Health Organization; 2000 [cited 2015 Nov 15]. p. 5-37. WHO Obesity Technical Report Series, n. 284. Available from: http://www.who.int/nutrition/ publications/obesity/WHO_TRS_894/en/

12. Nassar SM, Wronscki VR, Ohira M. SEstatNet Sistema Especialista para o Ensino de Estatística na Web [Internet]. Florianópolis (SC): 1999-2014. [cited 2015 Jun 18]. Available from: http:/ / www.sestatnet. ufsc.br/sestatnet.php

13. Winslow EH, Cooper SK, Haws DM, Balluck JP, Jones CM, Morse EC, et al. Unplanned perioperative hypothermia and agreement between oral, temporal artery, and bladder temperatures in adult major surgery patients. J Perianesth Nurs [Internet]. 2012 Jun [cited 2015 Nov 15]; 27(3):165-80. Available from: http:/ / ac.els-cdn.com/S108994721200072X/1s2.0-S108994721200072X-main.pdf?_tid=d14a981255dd-11e6-a046-00000aab0f6c\&acdnat=1469832366_ c38b50c8ea029db3d1db04f97b4f74dd

14. Prado CBC, Barichello E, Pires PS, Haas VJ, Barbosa $\mathrm{MH}$. Occurrence and factors associated with hypothermia during elective abdominal surgery. Acta Paul Enferm [Internet]. 2015 Jul-Aug [cited 2015 Dec 02]; 28(5):475-81. Available from: http:/ / www.scielo. br/pdf/ape/v28n5/en_1982-0194-ape-28-05-0475.pdf

15. Hooper VD, Chard R, Clifford T, Fetzer S, Fossum S, Godden B, et al. ASPAN's evidence-based clinical practice guideline for the promotion of perioperative normothermia: second edition. J Perianesth Nurs [Internet]. 2010 Dec [cited 2015 Nov 30]; 25(6):34665. Available from: http://ac-els-cdn-com.ez46. periodicos.capes.gov.br/S1089947210004120/1s2.0-S1089947210004120-main.pdf?_tid=2deaf04e55e3-11e6-9db9-00000aab0f27\&acdnat=1469834669_ a0dda6376d5f7482a4e9332c5ec52563

16. Monzón CGC, Aranaa CAC, Valzb HAM, Rodrígueza FA, Mejíac JJB, Gómeza JAA. Temperature management during the perioperative period and frequency of inadvertent hypothermia in a general hospital. Rev Colomb Anestesiol [Internet]. 2013 Apr-Jun [cited 2015 Nov 15]; 41(2):97-103. Available from: http:/ / ac.els-cdn.com/S2256208713000126/1s2.0-S2256208713000126-main.pdf?_tid=6c2fb95c55e3-11e6-ba4d-00000aab0f27\&acdnat=1469834774_ c214f38fadfdf21ccfb1a50094f5feb9

17. Fernandes LA, Braz LG, Koga FA, Kakuda CM, Módolo NSP, Carvalho LR, et al. Comparison of peri-operative core temperature in obese and non-obese patients. Anaesthesia [Internet]. 2012 Dec [cited 2015 Dec 30]; 67(12):1364-9. Available from: http://onlinelibrary. wiley.com/doi/10.1111/anae.12002.x/epdf

18. Mattia AL, Barbosa MH, Freitas Filho JPA, Rocha AM, Pereira NHC. Warmed intravenous infusion for controlling intraoperative hypothermia. Rev Latinoam Enfermagem [Internet]. 2013 May-Jun [cited 2015 Dec 30]; 21(3):803-10. Available from: http://www. scielo.br/pdf/rlae/v21n3/0104-1169-rlae-21-03-0803. pdf 
19. Mattia AL, Barbosa MH, Rocha AM, Pereira NHC. Hipotermia em pacientes na recuperação pósanestésica: análise da intervenção de infusão venosa aquecida. Rev Eletr Enferm [Internet]. 2014 Out-Dez [cited 2015 May 17]; 16(4):787-94. Available from: https://www.fen.ufg.br/fen_revista/v16/n4/pdf/ v16n4a11.pdf

20. National Institute for Health and Care Evidence. Clinical practice guidelines: the management of inadvertent perioperative hypothermia in adults [Internet]. Emergency Nurses Association; 2011 Dec [cited 2015 Jul 18]. Available from: www.nice.org.uk/ CG65

21. Amante LN, Slomochenski LA, Teixeira MGPN, Bertoncello KCG. Ocorrência de hipotermia não planejada em sala de recuperação anestésica. UNOPAR Cient, Ciênc Biol Saúde [Internet]. 2012 Out [cited 2015 May 17]; 14(4):211-5. Available from: http://pgsskroton.com.br/seer/index.php/ JHealthSci/article/view/828/793

22. Biazzotto $C B$, Brudniewski M, Schmidt AP, Auler Júnior JOC. Perioperative hypothermia. Rev Bras Anestesiol [Internet]. $2006 \mathrm{Jan}-\mathrm{Fev}$ [cited $2016 \mathrm{Jul}$ 29]; 56(1):89-106. Available from: http://www. scielo.br/scielo.php?script=sci_arttext\&pid=S0034- 70942006000100012\&lng=en\&nrm=iso\&tlng=en

23. Hart SR, Bordes B, Hart J, Corsino D, Harmon D. Unintended perioperative hypothermia. Ochsner J [Internet]. 2011 [cited 2016 Jul 29]; 11:259-270. Available from: http://www.ncbi.nlm.nih.gov/pmc/ articles/PMC3179201/

24. Association of periOperative Registered Nurses. Recommended practices for sterilization. In: Association of periOperative Registered Nurses AORN. Perioperative standards and recommended practices. Denver: AORN; 2013. p. 513-4.

25. Poveda VB, Santos B, Galvão CM. Análise entre o tempo cirúrgico e as variações da temperatura e da umidade em sala de operação. Rev SOBECC [Internet]. 2014 Abr-Jun [cited 2015 Dec 02]; 19(2):61-6. Available from: http://itarget.com.br/newclients/sobecc.org. br/2015/pdfs/site_sobecc_v19n2/01_sobecc_v19n2. pdf

26. Caldana G, Guirardello EB, Urbanetto JS, Peterlini MAS, Gabriel CS. Brazilian Network for Nursing and Patient Safety: challenges and perspectives. Texto Contexto Enferm [Internet]. 2015 Jul-Sep [cited 2015 Dec 02]; 24(3):906-11. Available from: http:/ /www. scielo.br/pdf/tce/v24n3/0104-0707-tce-24-03-00906. pdf 